\title{
Cobalt(II) and Zinc(II) Complexes of Hexamethylenetetramine as Single Source Precursors for their Metal Oxide Nanoparticles
}

\author{
Che Dieudonne Tabong ${ }^{1}$, Agwara Moise Ondoh ${ }^{1}$, Divine Mbom Yufanyi ${ }^{2} \&$ Josepha Foba $^{3}$ \\ ${ }^{1}$ Department of Inorganic Chemistry, Faculty of Science, University of Yaounde I, Yaounde, Cameroon \\ ${ }^{2}$ Department of Chemistry, Faculty of Science, The University of Bamenda, Bamenda, Cameroon \\ ${ }^{3}$ Department of Chemistry, Faculty of Science, University of Buea, Cameroon \\ Correspondence: Agwara Moise Ondoh, Department of Inorganic Chemistry, Faculty of Science, University of \\ Yaounde I, Yaounde, Cameroon. E-mail: agwara29@yahoo.com
}

Received: August 17, 2015 Accepted: September 2, 2015 Online Published: September 14, 2015

doi:10.5539/jmsr.v4n4p70 URL: http://dx.doi.org/10.5539/jmsr.v4n4p70

\begin{abstract}
$\mathrm{Co}_{3} \mathrm{O}_{4}$ and $\mathrm{ZnO}$ nanoparticles with different morphologies were synthesised by the thermal decomposition of single source precursors obtained from readily available and eco-friendly starting materials (hexamethylenetetramine and metal nitrates). The precursors, which were characterized by elemental analysis, Fourier transform infrared spectroscopy (FTIR), X-ray diffraction and thermal gravimetric analysis, were calcined at $500^{\circ} \mathrm{C}$ for $2 \mathrm{~h}$, and the oxide samples obtained were characterized by FTIR, X-ray diffraction (XRD), field emission scanning electron microscopy (FESEM), transmission electron microscopy (TEM), selected area electron diffraction (SAED), and nitrogen physisorption. XRD showed that the oxides obtained were crystalline and free of extraneous impurity phases. The morphology of the nanoparticles obtained changed from cube-like $\left(\mathrm{Co}_{3} \mathrm{O}_{4}\right)$ to hexagonal-prism like morphology $(\mathrm{ZnO})$, while the particle size increased from 19.6 to $64.5 \mathrm{~nm}$, respectively. The method used simple and cheap precursors, which should make it suitable for large-scale synthesis.
\end{abstract}

Keywords: Cobalt oxide, Zinc oxide, Nanoparticle, Thermal decomposition, Hexamethylenetetramine, XRD

\section{Introduction}

Metal oxide nanoparticles constitute a class of functional materials on which much attention has been focused recently due to their morphology and size-dependent physical and chemical properties (Devan, Patil, Lin, \& Ma, 2012; Niederberger, 2007).

The size reduction of these metal oxides, which leads to novel properties that are different from those of the individual atoms as well as their bulk counterparts, makes them potential materials for application in the fields of catalysis, electronics, storage devices, gas sensors and magnetic resonance imaging (de Rivas, López-Fonseca, Jiménez-González, \& Gutiérrez-Ortiz, 2012; Devan et al., 2012; Gomez \& Tigli, 2013; Kahn et al., 2009).

Among these metal oxide nanoparticles, nanoscale cobalt and zinc oxides have received much scientific attention because they have interesting size-dependent physico-chemical properties for material as well as industrial applications. Cobalt oxide, especially the cubic $\mathrm{Co}_{3} \mathrm{O}_{4}$ phase with a spinel structure (Fd3m), is a p-type semiconductor which has been employed in several technological applications in the field of heterogeneous catalysis (Che, Liu, Fu, \& Jiang, 2013; de Rivas et al., 2012), supercapacitors (Vijayakumar, Ponnalagi, Nagamuthu, \& Muralidharan, 2013; H. Xu et al., 2014 ), anode materials in lithium ion rechargeable batteries (Huang et al., 2014; Rui et al., 2013), and magnetic materials (Moro, Yu Tang, Tuna, \& Lester, 2013; Sharma \& Jeevanandam, 2013).

$\mathrm{ZnO}$ is a thermally and chemically stable semiconducting material with a wide band gap of $3.37 \mathrm{eV}$ and a large exciton binding energy of $60 \mathrm{meV}$ at room temperature. It has found application in the domains of gas sensors, catalysis and optical devices (Faisal, Khan, Rahman, Jamal, \& Abdullah, 2012; Gomez \& Tigli, 2013; Guo \& Peng, 2015; Hirai \& Asada, 2005; Karami, Eskandari, Khodabakhshi, Hoseini, \& Hashemian, 2013; Pál et al., 2012; Xiong, Ma, Wang, \& Xia, 2011). ZnO is also biocompatible, nontoxic, chemically stable, and electrochemically active; properties which have enabled its application in biosensing (Gomez \& Tigli, 2013). 
Various methods have been employed for the morphology-controlled synthesis of $\mathrm{Co}_{3} \mathrm{O}_{4}$ and $\mathrm{ZnO}$ nanoparticles, which include microwave-assisted synthesis (Faisal et al., 2012; Vijayakumar et al., 2013), Chemical precipitation (Greene, Yuhas, Law, Zitoun, \& Yang, 2006; Romo et al., 2011; Rui et al., 2013), hydrothermal (Dakhlaoui, Jendoubi, Smiri, Kanaev, \& Jouini, 2009; Lester et al., 2012; Moro et al., 2013; Pál et al., 2012; Rui et al., 2013), sonochemical (Banerjee, Chakrabarti, Maitra, \& Dutta, 2012), solvothermal synthesis (Y. Xu, Wang, Sun, Zhang, \& Gao, 2010), pulsed layer deposition (Warang et al., 2012), and biosynthesis (Fu \& Fu, 2015). These varied methods have led to nanoparticles with diverse morphologies like nanocubes (Lester et al., 2012), nanorods (Fu \& Fu, 2015; Romo et al., 2011), nanospheres (Dakhlaoui et al., 2009; Darezereshki, Alizadeh, Bakhtiari, Schaffie, \& Ranjbar, 2011; Hirai \& Asada, 2005), nanowires (Greene et al., 2006), nanoflowers (Pál et al., 2012), and nanotubes (Li, Dou, \& Bao, 2012).

These conventional methods, though successful, require specially designed and expensive equipment, extra purification steps, rigorous reaction conditions and/or relatively high temperatures. Some of the solution-based synthetic approaches employ surfactants and solvents which are toxic and not easily degraded in the environment. The synthesis of these nanomaterials with controlled size and shape is still a major challenge and large scale synthesis of phase pure $\mathrm{Co}_{3} \mathrm{O}_{4}$ and $\mathrm{ZnO}$ nanoparticles at relatively low temperatures, using readily available, environmentally benign and cost-effective precursors is a synthetic challenge. Thus, the preparation of cobalt oxide and zinc oxide nanoparticles by thermal decomposition of cobalt and zinc complexes becomes increasingly important mainly due to its cost-effectiveness, careful choice of precursors and calcination conditions, high yields, easy control of synthesis conditions, particle size, crystal structure, and purity. For example, the synthesis of metal oxide nanoparticles by the thermal decomposition of organometallic compounds or metal complexes has been reported (Ahmad, Ganguly, Ahmed, Ganguli, \& Alhartomy, 2011; Huang et al., 2014; Kahn et al., 2009; Palacios-Hernández et al., 2012; Sharma \& Jeevanandam, 2013). Porous $\mathrm{Co}_{3} \mathrm{O}_{4}$ with different morphologies has been prepared by the thermal decomposition of cobalt carbonates $\left(300-500^{\circ} \mathrm{C}\right.$ for 2 $-3 \mathrm{~h}$ ) and oxalate precursors $\left(400-500^{\circ} \mathrm{C}\right.$ for 6 h) (Che et al., 2013; de Rivas et al., 2012; Nassar \& Ahmed, 2011). Rivas et al. obtained $\mathrm{Co}_{3} \mathrm{O}_{4}$ by the direct calcination of cobalt nitrate and cobalt oxalate nanorods at $500^{\circ} \mathrm{C}$ (de Rivas et al., 2012). $\mathrm{Co}_{3} \mathrm{O}_{4}$ nanoparticles were obtained by solid-state thermal decomposition of a Schiff base complex [ $\left.\mathrm{CoL}_{3}\right]\left(\mathrm{L}=\mathrm{N}\right.$-salicylidin-2-chloroethylimine) at $450^{\circ} \mathrm{C}$ under air atmosphere for $3 \mathrm{~h}$ (Khalaji, Nikookar, Fejfarova, \& Dusek, 2014). Hongwei and co-workers prepared $\mathrm{Co}_{3} \mathrm{O}_{4}$ microdiscs by a thermal decomposition of cobalt oxalate at $400^{\circ} \mathrm{C}$, obtained by the solvothermal reaction of cobalt nitrate and ammonium oxalate in anhydrous alcohol (Che et al., 2013). $\mathrm{Co}_{3} \mathrm{O}_{4}$ nanoparticles were prepared via the decomposition of the pentammine(carbonato)cobalt(III) nitrate precursor complex $\left[\mathrm{Co}\left(\mathrm{NH}_{3}\right)_{5} \mathrm{CO}_{3}\right] \mathrm{NO}_{3} \cdot 0.5 \mathrm{H}_{2} \mathrm{O}$ at low temperature $\left(175^{\circ} \mathrm{C}\right)$ (Farhadi \& Safabakhsh, 2012). Palacios-Hernandez et al. reported the synthesis of $\mathrm{Cu}$ and $\mathrm{Co}$ metal oxide nanoparticles by the thermal decomposition of the corresponding tartrate complexes $\left(\left[\mathrm{M}\left(\mathrm{C}_{4} \mathrm{H}_{2} \mathrm{O}_{6}\right)_{\mathrm{n}}\right]_{\mathrm{m}}, \mathrm{M}=\mathrm{Cu}(\mathrm{II}), \mathrm{Co}(\mathrm{II})\right)$ at $500^{\circ} \mathrm{C}$ for $5 \mathrm{~h}$ (Palacios-Hernández et al., 2012). Aghababazadeh et al. prepared $\mathrm{ZnO}$ nanoparticles by the thermal decomposition $\left(170-380^{\circ} \mathrm{C}\right)$ of $\mathrm{ZnCO}_{3}$ obtained by mechanochemical processing (Aghababazadeh, Mazinani, Mirhabibi, \& Tamizifar, 2006). Hirai and co-workers obtained ZnO nanoparticles by the calcination of $\mathrm{Zn}(\mathrm{OH})_{2}$ nanoparticles, which were prepared in a polyethylene glycol mono-4-nonylphenyl ether (NP-5)/cyclohexane reverse micellar system and incorporated into polyurea via an in situ polymerization of hexamethylene diisocyanate (Hirai \& Asada, 2005). Rajesh et al. prepared $\mathrm{ZnO}$ nanoparticles by the mechanochemical synthesis of $\mathrm{ZnC}_{2} \mathrm{O}_{4} \cdot 2 \mathrm{H}_{2} \mathrm{O}$ nanoparticles followed by its thermal decomposition at $400^{\circ} \mathrm{C}$ (Rajesh, Vara Lakshmi, \& Sunandana, 2012). Spherical ZnO nanoparticles have also been prepared by the thermal decomposition of $\mathrm{Zn}_{4}\left(\mathrm{SO}_{4}\right)(\mathrm{OH})_{6} \cdot 0.5 \mathrm{H}_{2} \mathrm{O}$ in air for $1 \mathrm{~h}$ at $825^{\circ} \mathrm{C}$ (Darezereshki et al., 2011).

The high costs, use of non-ecofriendly surfactants and solvents as well as the evolution of very toxic gaseous products during calcination, limits the use of some of these precursors. In continuation of our interest in the synthesis of phase pure metal oxide nanoparticles, we report herein a simple, environmentally benign and cost-effective method to synthesize $\mathrm{Co}_{3} \mathrm{O}_{4}$ and $\mathrm{ZnO}$ nanoparticles by the thermal decomposition of their respective metal-hexamethylenetetramine (M-HMTA) complexes. Hexamethylenetetramine (HMTA) is a cheap, ecofriendly and readily available heterocyclic organic compound with a cage-like structure. It is highly soluble in water and polar organic solvents. Some metal complexes of HMTA had previously been used as precursors for metal dispersions (Afanasiev et al., 2008), metal carbides and nitrides (Chouzier, Afanasiev, Vrinat, Cseri, \& Roy-Auberger, 2006; Chouzier, Vrinat, Cseri, Roy-Auberger, \& Afanasiev, 2011), and oxide nanoparticles (Yufanyi, Tendo, Ondoh, \& Mbadcam, 2014). 


\section{Method}

\subsection{Materials}

$\mathrm{Co}\left(\mathrm{NO}_{3}\right)_{2} .6 \mathrm{H}_{2} \mathrm{O}, \mathrm{Zn}\left(\mathrm{NO}_{3}\right)_{2} .6 \mathrm{H}_{2} \mathrm{O}$, hexamethylenetetramine and ethanol were obtained from Sigma Aldrich. All the chemicals were of analytical grade and were used as obtained without further purification.

\subsection{Synthesis of Metal(II) - HMTA Complex}

The precursors were synthesized according to a procedure previously reported for a polymeric $\mathrm{Co}(\mathrm{HMTA})_{2}\left(\mathrm{NO}_{3}\right)_{2}\left(\mathrm{H}_{2} \mathrm{O}\right)_{2}$ complex, with slight modifications (Ndifon et al., 2009).

HMTA (4 mmol; $0.5608 \mathrm{~g}$ ) was dissolved in $20 \mathrm{~mL}$ of ethanol/water mixture $(6: 1 \mathrm{v} / \mathrm{v})$ by sonicating for 20 minutes, at room temperature. The solution was magnetically stirred while stoichiometric amounts of the metal nitrate $(2 \mathrm{mmol})$ in $10 \mathrm{~mL}$ of ethanol was added drop wise to the HMTA solution and the mixture was stirred for two hours. The pink precipitate (Co-HMTA) and the white precipitate (Zn-HMTA) that were obtained were filtered, washed several times with $99 \%$ ethanol and dried in a desiccator over silica gel. Pink crystals (Co-HMTA) and colourless crystals (Zn-HMTA) suitable for single crystal XRD were obtained from the filtrates within two weeks.

\subsection{Synthesis of Cobalt and Zinc Oxide Nanoparticles}

The dry M-HMTA complex $(0.5 \mathrm{~g})$ was ground and placed in a ceramic crucible that had previously been washed, dried and weighed. The crucible was placed into a furnace and heated at a ramp rate of $5^{\circ} \mathrm{C}$ per minute until the desired temperature was reached $\left(500^{\circ} \mathrm{C}\right)$ and calcined in the presence of air for two hours. The sample was allowed to cool slowly to room temperature. The obtained black powder (case of cobalt) and the white product (case of zinc) were weighed and could easily be re-dispersed in water and ethanol. The samples are referred to as $\mathrm{Co}_{3} \mathrm{O}_{4}-500$ and $\mathrm{ZnO}-500$.

\subsection{Characterisation}

Elemental analysis $(\mathrm{C}, \mathrm{H}, \mathrm{N})$ of the precursor was carried out on a Flash 2000 Thermo Scientific analyser while the FT-IR spectra were recorded from 4000 to $400 \mathrm{~cm}^{-1}$ on a PerkinElmer Spectrum Two universal attenuated total reflectance Fourier transform infrared (UATR-FT-IR) spectrometer.

Single crystal X-ray data were collected using a graphite monochromatic Mo-Ka radiation $(\lambda=1.54178 \AA)$ from a Bruker APEX diffractometer. The structures were solved by direct methods and refined by full-matrix least squares on $\mathrm{F}^{2}$ (Sheldrick, 1997a, 1997b). The non-hydrogen atoms were refined anisotropically. $\mathrm{H}$ atoms were included in calculated positions with $\mathrm{C}-\mathrm{H}$ lengths of $0.95(\mathrm{CH})$, assigned isotopic thermal parameters and allowed to ride on their parent carbon atoms. All calculations were carried out using the SHELXTL package (Bruker, 2001).

Thermogravimetric measurements were obtained using a Pyris 6 PerkinElmer TGA 4000 thermal analyser. The TGA analyses were conducted between 30 and $900^{\circ} \mathrm{C}$ under nitrogen atmosphere at a flow rate of $20 \mathrm{~mL} / \mathrm{min}$ and a temperature ramp of $10^{\circ} \mathrm{C} / \mathrm{min}$. The XRD diffractogram were recorded on a Bruker D8 Advance X-ray diffractometer using a $\mathrm{Cu} \mathrm{K} \alpha$ radiation source $(\lambda=0.15406 \mathrm{~nm}, 40 \mathrm{kV}$ and $40 \mathrm{~mA})$. Scans were taken over the $2 \theta$ range from $10^{\circ}$ to $100^{\circ}$ in steps of $0.01^{\circ}$ at room temperature in open quartz sample holders. The phases were identified with the help of the Bruker DIFFRACplus evaluation software in combination with the ICDD powder diffraction data base (International Centre for Diffraction Data). FESEM images and energy dispersive X-ray (EDX) spectra were obtained on a JEOL JSM-7600F field-emission scanning electron microscope (FESEM), with a lens diameter of $800 \mathrm{~mm}^{2}$ (Oxford Instruments Ltd, UK) coupled to a silicon drift energy-dispersive X-ray detector. Transmission electron microscopy (TEM) was performed on a JEOL JEM-2100F microscope using a maximum acceleration voltage of $200 \mathrm{kV}$ from the field emission gun. The particle size distributions were determined from the TEM images using the ImageJ software. $\mathrm{N}_{2}$-physisorption experiments for the determination of the total surface area and the average pore diameter were conducted on a Micromeritics ASAP 2020 instrument. Prior to the measurement, the samples were degassed at $200^{\circ} \mathrm{C}$ for $6 \mathrm{~h}$.

\section{Results and Discussion}

By careful choice of the precursor, coupled with a rational control of temperature and other conditions, nano-sized cobalt and zinc oxides were obtained by thermal decomposition of their corresponding hexamethylenetetramine (HMTA) complexes. These complexes were prepared in a single step, in high yield at room temperature.

The elemental analytical data of the precursors (Table 1) correspond closely to the empirical formulae $\mathrm{CoC}_{12} \mathrm{H}_{28} \mathrm{~N}_{10} \mathrm{O}_{8}$ and $\mathrm{ZnC}_{12} \mathrm{H}_{44} \mathrm{~N}_{10} \mathrm{O}_{16}$ which matches the structural formulae [Co(HMTA $)_{2}\left(\mathrm{H}_{2} \mathrm{O}\right)_{2}\left(\mathrm{NO}_{3}\right)_{2}$ ] and $\left[\mathrm{Zn}\left(\mathrm{H}_{2} \mathrm{O}\right)_{6}\right](\mathrm{HMTA})_{2}\left(\mathrm{NO}_{3}\right)_{2} \cdot 4 \mathrm{H}_{2} \mathrm{O}$, respectively, for cobalt and zinc. 
Table 1. Elemental analytical data of the complexes

\begin{tabular}{cccccc}
\hline \multirow{2}{*}{ Complex } & \multirow{2}{*}{ Yield (\%) } & Colour & \multicolumn{3}{c}{ Elemental Analysis: \% Found (\% Calc.) } \\
\cline { 5 - 7 } & & & $\% \mathrm{C}$ & $\% \mathrm{H}$ & \multicolumn{1}{c}{$\% \mathrm{~N}$} \\
\hline$\left[\mathrm{Co}(\mathrm{HMTA})_{2}\left(\mathrm{H}_{2} \mathrm{O}\right)_{2}\left(\mathrm{NO}_{3}\right)_{2}\right]$ & 85 & Pink crystals & $28.73(28.86)$ & $5.82(5.65)$ & $27.56(28.05)$ \\
{$\left[\mathrm{Zn}\left(\mathrm{H}_{2} \mathrm{O}\right)_{6}\right](\mathrm{HMTA})_{2}\left(\mathrm{NO}_{3}\right)_{2} \cdot 4 \mathrm{H}_{2} \mathrm{O}$} & 78 & Colourless crystals & $22.21(22.18)$ & $6.74(6.82)$ & $21.23(21.55)$ \\
\hline
\end{tabular}

\subsection{X-ray Crystal Structure}

The crystal structures of the precursors Co-HMTA and Zn-HMTA were found to be the same as those of the complexes $\left[\mathrm{Co}(\mathrm{HMTA})_{2}\left(\mathrm{H}_{2} \mathrm{O}\right)_{2}\left(\mathrm{NO}_{3}\right)_{2}\right]$ (Ndifon et al., 2009) and $\left[\mathrm{Zn}\left(\mathrm{H}_{2} \mathrm{O}\right)_{6}\right](\mathrm{HMTA})_{2}\left(\mathrm{NO}_{3}\right)_{2} \cdot 4 \mathrm{H}_{2} \mathrm{O}$ (Singh et al., 2008) respectively, found in literature.

\subsection{FTIR Analyses of the Precursor Complexes}

The relevant infrared bands of HMTA and the precursor complexes are listed in Table 2, while the FTIR spectra of the precursor complexes and the corresponding oxides are shown in Figure 1. The broad bands at $3400-3501 \mathrm{~cm}^{-1}$ in the spectra of M-HMTA are attributed to $v(\mathrm{OH})$ of coordinated water, while that at $3383 \mathrm{~cm}^{-1}$ is assigned to $v(\mathrm{OH})$ of lattice water (Hee Ng, Guan Teoh, Moris, \& Yang Yap, 2004). The band at $1235 \mathrm{~cm}^{-1}$, assigned to the $v\left(\mathrm{CH}_{2}\right)$ rocking vibration of the free HMTA ligand is observed at $1238 \mathrm{~cm}^{-1}$ in the Zn-HMTA complex, while it is split into 1240 and $1227 \mathrm{~cm}^{-1}$ in the Co-HMTA precursor suggesting that HMTA is coordinated to the cobalt ion (Ndifon et al., 2009). Strong prominent peaks at 812 and $1000 \mathrm{~cm}^{-1}$ due to the C-N stretching vibration of HMTA are shifted to $818-819 \mathrm{~cm}^{-1}$ and $1002 \mathrm{~cm}^{-1}$, respectively in the Co-HMTA and Zn-HMTA precursor complexes (Jensen, 2002). The weak band observed at $1780 \mathrm{~cm}^{-1}$ shows the coordination of a monodentate nitrate ion, $\mathrm{Co}-\mathrm{NO}_{3}$ (Ndifon et al., 2009). The coordination of water molecules is also indicated by the IR bands in the region 400-600 $\mathrm{cm}^{-1}$, assigned to $\mathrm{M}-\mathrm{H}_{2} \mathrm{O}$ (Ndifon et al., 2009).

Table 2. Relevant FTIR bands of HMTA and the M-HMTA precursor complexes

\begin{tabular}{cccc}
\hline $\mathrm{HMTA}$ & {$\left[\mathrm{Co}(\mathrm{HMTA})_{2}\left(\mathrm{NO}_{3}\right)_{2}\left(\mathrm{H}_{2} \mathrm{O}\right)_{2}\right]$} & {$\left[\mathrm{Zn}\left(\mathrm{H}_{2} \mathrm{O}\right)_{6}\right](\mathrm{HMTA})_{2}\left(\mathrm{NO}_{3}\right)_{2} \cdot 4 \mathrm{H}_{2} \mathrm{O}$} & Band Assignments \\
\hline- & 3501 & 3480 & $v(\mathrm{OH})$ (coordinated water) \\
- & - & 3383 & $v(\mathrm{OH})$ (lattice water) \\
2955 & - & 2970 & $v\left(\mathrm{CH}_{2}\right)$ \\
- & 1780 & - & $\mathrm{Co}-\mathrm{NO}_{3}$ \\
- & 1675 & 1674 & $\mathrm{HOH}$ bend (lattice water) \\
1457 & 1475 & 1463 & $v\left(\mathrm{CH}_{2}\right)$ scissor (HMTA) \\
1370 & 1349 & 1343 & $v\left(\mathrm{CH}_{2}\right)$ wag (HMTA) \\
1236 & 1240 & 1238 & $v\left(\mathrm{CH}_{2}\right)$ rock (HMTA) \\
& 1227 & & \\
1000 & 1002 & 1002 & $v(\mathrm{CN})$ stretch (HMTA) \\
811 & 819 & 818 & $v(\mathrm{CN})$ stretch (HMTA) \\
670 & 682 & 687 & N-C-N bend (HMTA) \\
- & 504 & 505 & M-O stretch \\
\hline
\end{tabular}

\subsection{Thermogravimetric Analysis}

The TG curves of the precursor complexes are presented in Figure 2 and summarised in Table 3. The curves indicate that both complexes decompose in more than one step to give the metal oxides. The thermal decomposition of these precursors is accompanied by the evolution of a mixture of gases. 


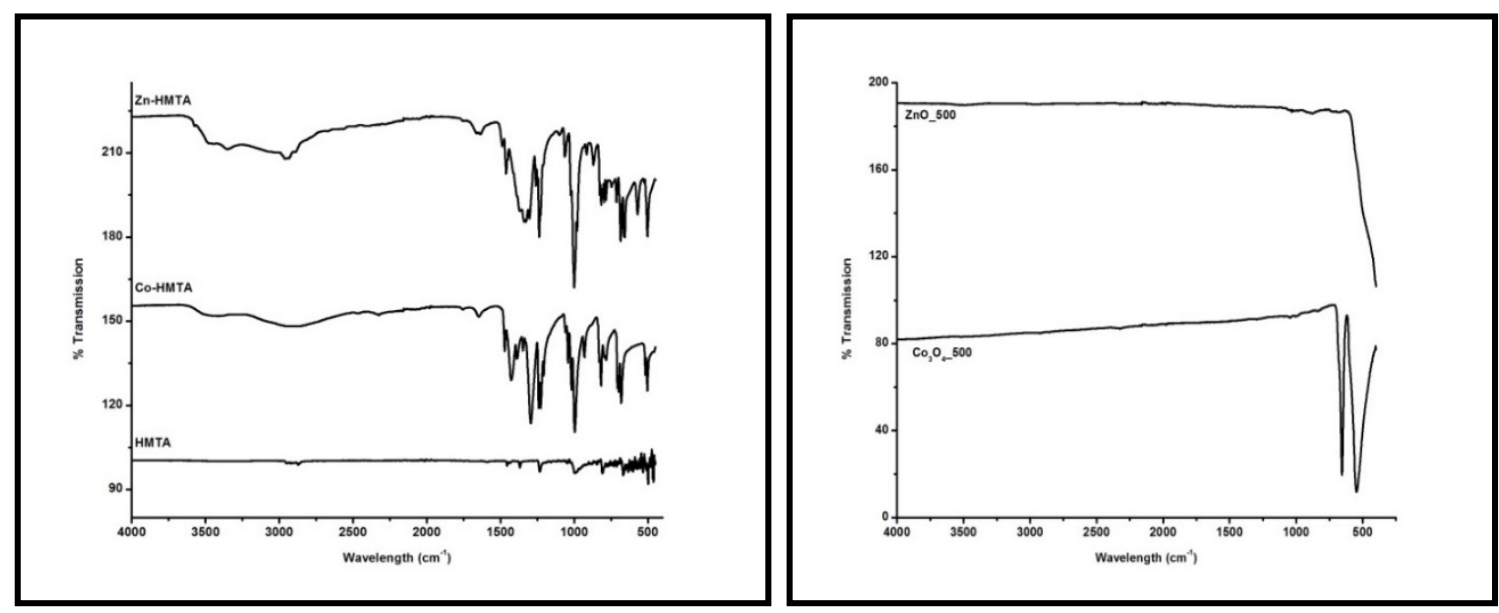

Figure 1. FTIR spectra of HMTA, the precursor complexes and the oxide nanoparticles

Table 3. Thermal decomposition data for the precursor complexes

\begin{tabular}{ccccc}
\hline \multirow{2}{*}{ Complex } & \multirow{2}{*}{ Step } & \multirow{2}{*}{ Temperature range $\left({ }^{\circ} \mathrm{C}\right)$} & \multicolumn{2}{c}{$\%$ Mass Loss } \\
\cline { 4 - 5 } & & & Obs. & Calc. \\
\hline$\left[\mathrm{Co}(\mathrm{HMTA})_{2}\left(\mathrm{NO}_{3}\right)_{2}\left(\mathrm{H}_{2} \mathrm{O}\right)_{2}\right]$ & I & $135-198$ & 8.5 & 10.02 \\
& II & $200-315$ & 53.6 & 56 \\
{$\left[\mathrm{Zn}\left(\mathrm{H}_{2} \mathrm{O}\right)_{6}\right](\mathrm{HMTA})_{2}\left(\mathrm{NO}_{3}\right)_{2} \cdot 4 \mathrm{H}_{2} \mathrm{O}$} & II & $320-540$ & 13.6 & 12.4 \\
& II & $40-100$ & 14.8 & 13.8 \\
& III & $105-153$ & 4.71 & 5.5 \\
& IV & $420-740$ & 23.4 & 27.4 \\
\hline
\end{tabular}

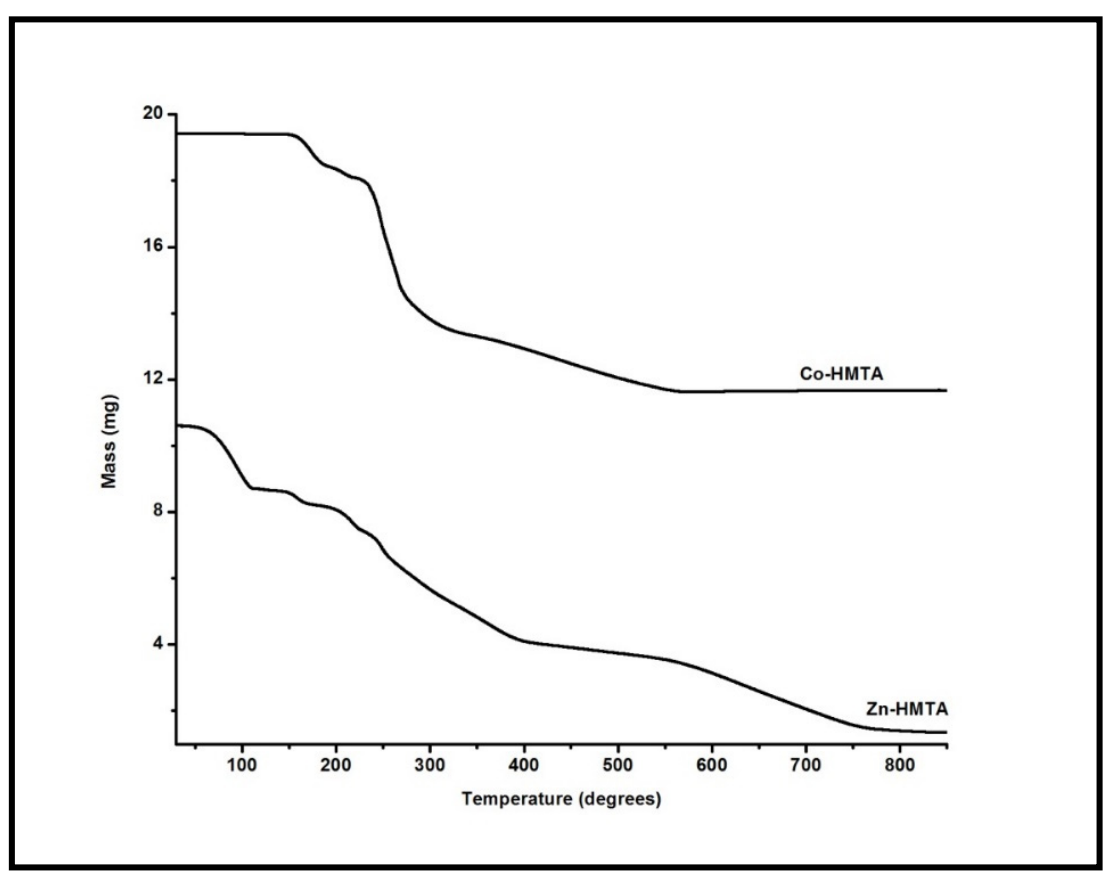

Figure 2. TG curves of the precursor complexes 
For the Co-HMTA, the mass loss of $8.5 \%$ in the temperature region from $135-198^{\circ} \mathrm{C}$ is most probably due to the loss of two coordinated water molecules (10.02\%). The major mass loss of 53.6\% takes place in the range 200 $315^{\circ} \mathrm{C}$, and is attributed to the complete decomposition of HMTA $(56 \%)$ in the form of various gases (Afanasiev et al., 2008). In the range $320-540^{\circ} \mathrm{C}$ we have another distinctive decomposition step with a mass loss of $13.6 \%$ which can be assigned to the decomposition of the nitrate. A stable mass is reached at $540^{\circ} \mathrm{C}$. The calcination temperature was chosen as $500^{\circ} \mathrm{C}$ from the derivative $\mathrm{TG}$ plot.

Considering the decomposition of the Zn-HMTA complex, the mass loss of $14.8 \%$ in the temperature region from $50-102^{\circ} \mathrm{C}$ is attributed to the loss of five water molecules (13.8\%). The next decomposition step in the range 105 $-155^{\circ} \mathrm{C}$ with mass loss of $4.71 \%$ is probably due to the loss of two coordinated water molecules $(5.5 \%)$. In the temperature range $155-380^{\circ} \mathrm{C}$ which, from the derivative TG plots, consists of several overlapping decomposition steps, there is a major mass loss of $42.4 \%$ which can be assigned to the decomposition of two HMTA molecules (43.1\%) (Afanasiev et al., 2008; Hee Ng et al., 2004). The decomposition step in the range 400 $-740^{\circ} \mathrm{C}$ involves a mass loss of $23.4 \%$ which can be assigned to the decomposition of the two nitrates and two water molecules (calc. $27.4 \%$ ). A residual mass of $14.6 \%$ is observed at $740^{\circ} \mathrm{C}$ which is probably due to zinc metal $(10.1 \%)$.

The last decomposition step for Zn-HMTA is probably accompanied by the reduction of $\mathrm{ZnO}$ to zinc by carbon from $570^{\circ} \mathrm{C}$. From the Ellingham diagram, carbon will reduce zinc oxide above $950^{\circ} \mathrm{C}$ for $\mathrm{CO} / \mathrm{CO}_{2}$ ratio of 1 . In an oxygen deficient atmosphere, the ratio will probably decrease pushing the reduction temperature to the observed lower value.

The calcination temperature was chosen as $500^{\circ} \mathrm{C}$ from the derivative TG plot which indicates that $600^{\circ} \mathrm{C}$ is the optimum temperature. The decomposition pattern of the Zn-HMTA complex is slightly different from that reported in the literature, where the complex decomposes in two major steps in the temperature ranges $65-100^{\circ} \mathrm{C}$ and $600-645^{\circ} \mathrm{C}$ (Singh et al., 2008).

\subsection{Structural Characterisation of the Oxide Nanoparticles}

The FTIR spectra of the oxides are shown in Figure 1. The spectra show bands in the $500-650 \mathrm{~cm}^{-1}$ region which are attributed to the stretching vibration of the $\mathrm{M}-\mathrm{O}$ bond. The bands at 547 and $645 \mathrm{~cm}^{-1}$ for cobalt oxide, suggest the formation of spinel $\mathrm{Co}_{3} \mathrm{O}_{4}$ that is $\left(\mathrm{Co}^{2+}\right)\left(\mathrm{Co}^{3+}\right)_{2}\left(\mathrm{O}^{2-}\right)_{4}$ (Makhlouf, Abu-Zied, \& Mansoure, 2013; Nguimezong et al., 2014). These bands have been attributed to the $\left(\mathrm{Co}^{2+}\right)-\mathrm{O}-\left(\mathrm{Co}^{3+}\right)$ and to $\left(\mathrm{Co}^{3+}\right)-\mathrm{O}-\left(\mathrm{Co}^{3+}\right)$ vibrations, respectively (Makhlouf et al., 2013; Nguimezong et al., 2014).

The cobalt oxide and zinc oxide nanoparticles were obtained by thermal decomposition of their respective M-HMTA precursors at $500{ }^{\circ} \mathrm{C}$. The XRD patterns of $\mathrm{Co}_{3} \mathrm{O}_{4}$ and $\mathrm{ZnO}$ (Figure 3) indicate that pure and crystalline metal oxide phases are formed in both cases. The samples have well defined diffraction patterns. The peaks for $\mathrm{Co}_{3} \mathrm{O}_{4}$ correspond to the (111), (220), (311), (222), (400), (511) and (440) crystals planes and match the spinel structure of cubic $\mathrm{Co}_{3} \mathrm{O}_{4}$ JCPDS card no 43-1003 (space group: Fd3m) (Lester et al., 2012). The peaks for $\mathrm{ZnO}$ correspond to the (100), (002), (101), (102), (110), (103), (200), (112), and (201) crystal planes and match the wurtzite structure of hexagonal ZnO JCPDS card no. 36-1451 (Zhang, Ram, Stefanakos, \& Goswami, 2012). The average crystallite sizes determined by the Debye-Scherrer equation (Klug \& (Eds.), 1974) from the peak-width at half-height of the (311) peak for $\mathrm{Co}_{3} \mathrm{O}_{4}$ and the (101) peaks for $\mathrm{ZnO}$, were found to be 23 and $32.5 \mathrm{~nm}$ for $\mathrm{Co}_{3} \mathrm{O}_{4}-500$ and $\mathrm{ZnO}-500$, respectively.

The morphologies and other structural features of the precursor complexes, $\mathrm{Co}_{3} \mathrm{O}_{4}-500$ and $\mathrm{ZnO}-500$ samples were determined by FESEM, TEM and SAED. The FESEM images (Figure 4) show that the precursor complexes Co-HMTA (Figure 4a) and Zn-HMTA (Figure 4b) have spike-like and bar-like morphologies, respectively, while $\mathrm{Co}_{3} \mathrm{O}_{4}-500$ (Figure 4c) is highly porous and foam-like. The $\mathrm{ZnO}-500$ particles (Figure 4d) exhibit a rod-like shape. The formation of highly porous foam can be attributed to the large amounts of gases evolved when HMTA and nitrates decompose (Afanasiev et al., 2008).

The corresponding TEM images (Figure 5) confirm cube-like $\left(\mathrm{Co}_{3} \mathrm{O}_{4}\right)$ and hexagonal-prism like ( $\left.\mathrm{ZnO}\right)$ morphologies, with average particle sizes of 19.6 and $64.5 \mathrm{~nm}$, respectively. The average particle diameter was determined after a log normal fitting of the data obtained from the TEM images. The SAED images (Figure 5) show patterns corresponding to the polycrystalline nature of the $\mathrm{Co}_{3} \mathrm{O}_{4}$ and $\mathrm{ZnO}$ formed. 


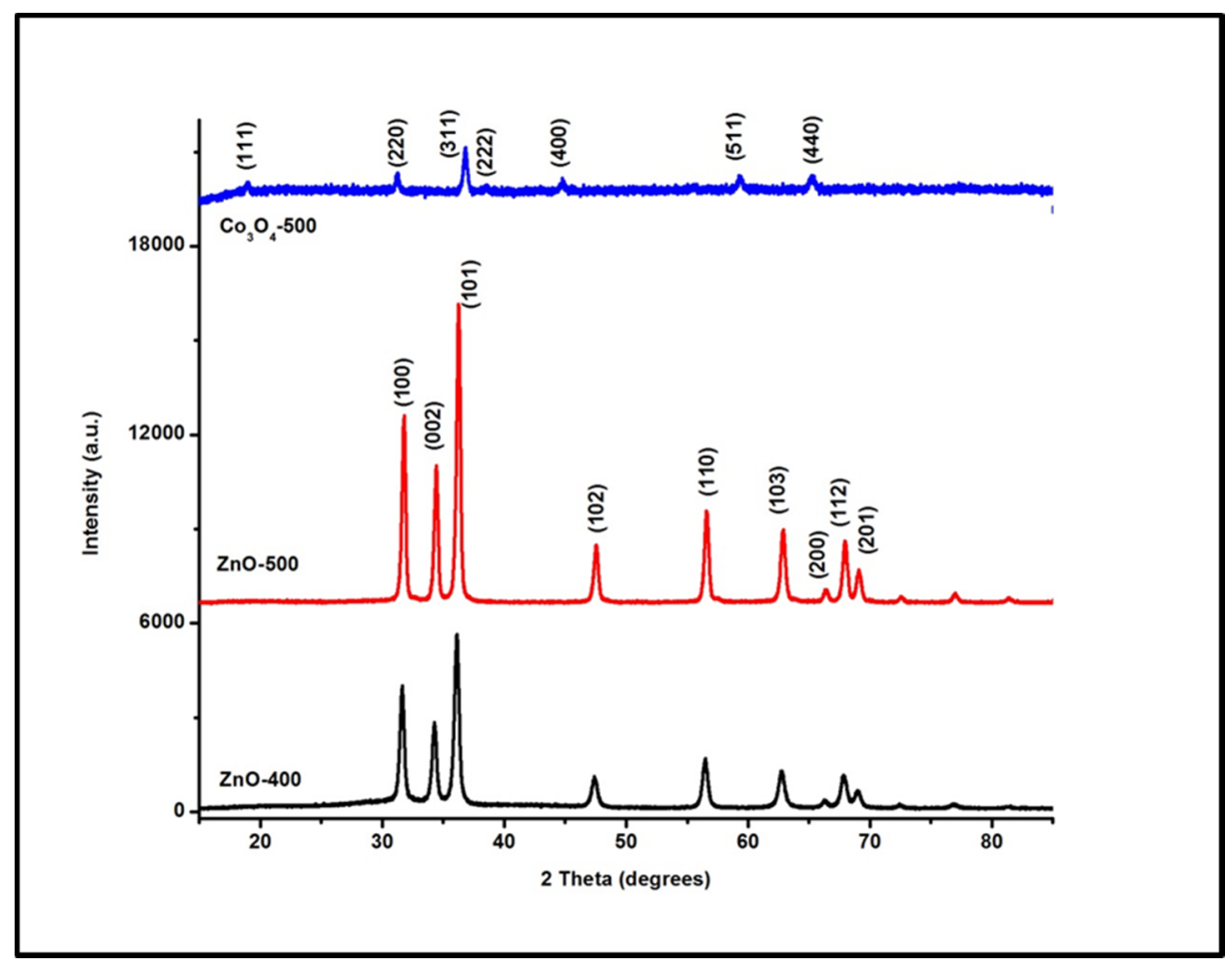

Figure 3. XRD patterns of $\mathrm{Co}_{3} \mathrm{O}_{4}-500, \mathrm{ZnO}-400$ and $\mathrm{ZnO}-500$ obtained by thermal decomposition
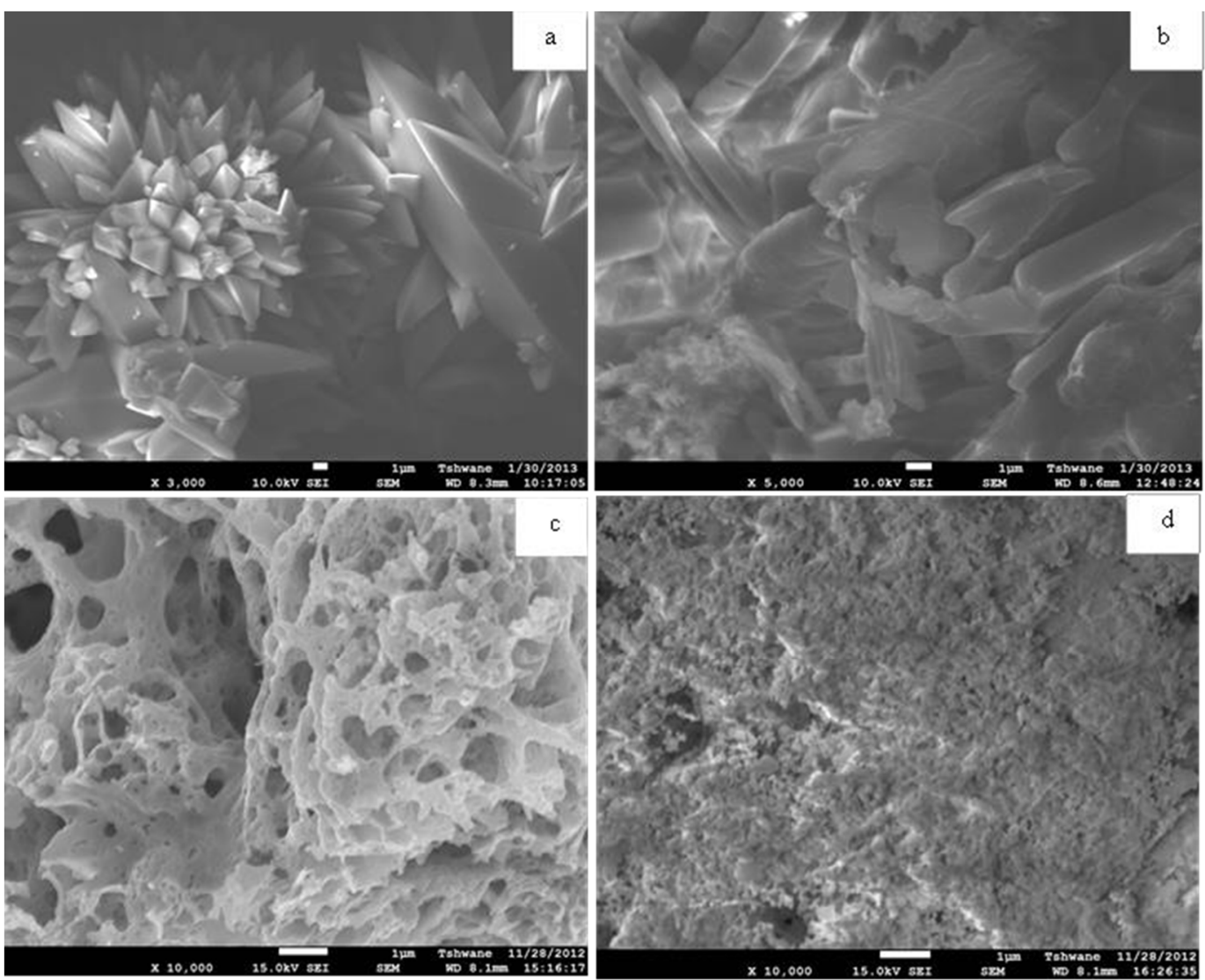

Figure 4. FESEM images of (a) Co-HMTA precursor; (b) Zn-HMTA precursor; (c) Co3O4-500 and (d) ZnO-500 

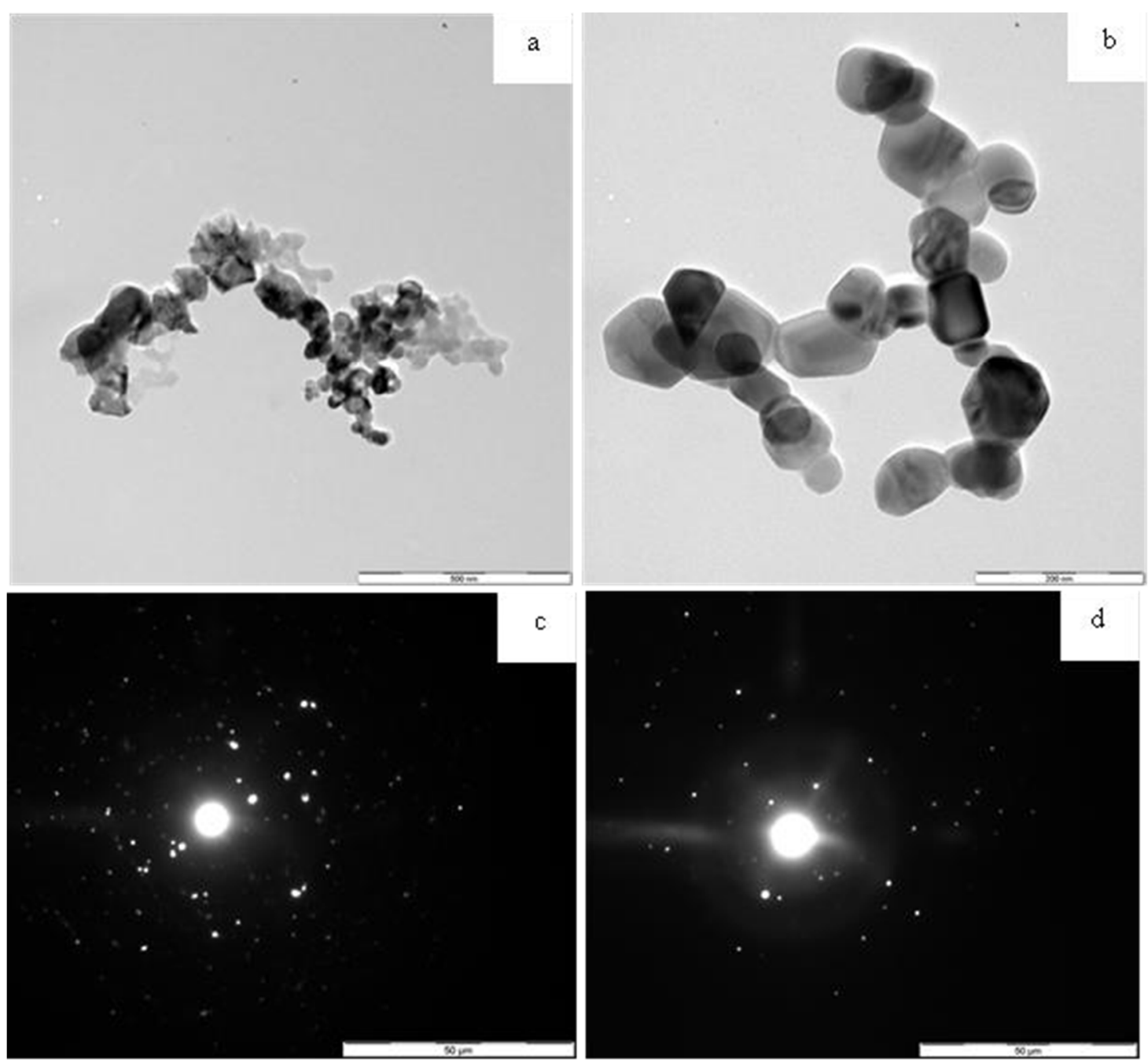

Figure 5. HRTEM images of (a) $\mathrm{Co}_{3} \mathrm{O}_{4}$ and (b) $\mathrm{ZnO}$; SAED images of (c) $\mathrm{Co}_{3} \mathrm{O}_{4}$ and (d) $\mathrm{ZnO}$

The particle size distributions and average particle sizes for $\mathrm{Co}_{3} \mathrm{O}_{4}-500$ and $\mathrm{ZnO}-500$ nanoparticles are shown in Figure 6. From this histogram it is observed that the particle sizes for $\mathrm{Co}_{3} \mathrm{O}_{4}-500$ and $\mathrm{ZnO}-500$ vary from $15-25$ $\mathrm{nm}$ and $45-85 \mathrm{~nm}$, respectively. The average particle sizes from TEM are consistent with values obtained by XRD.
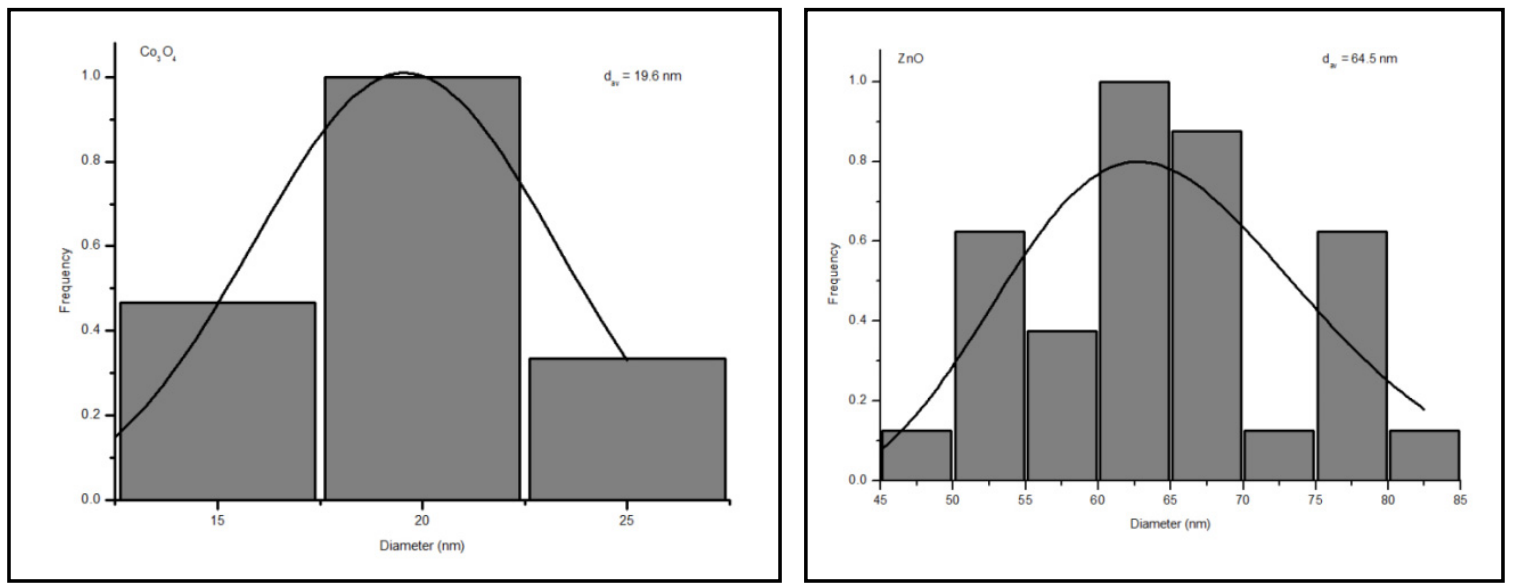

Figure 6. Particle size distribution for $\mathrm{Co}_{3} \mathrm{O}_{4}-500$ and $\mathrm{ZnO}-500$ nanoparticles 
For comparison, the precursors, decomposition time and temperatures used to obtain $\mathrm{Co}_{3} \mathrm{O}_{4}-500$ and $\mathrm{ZnO}-500$ nanoparticles by thermal decomposition, with various morphologies and sizes, found in the literature are listed in Table 4. The results show that cube-like $\left(\mathrm{Co}_{3} \mathrm{O}_{4}-500\right)$ and hexagonal-like (ZnO-500) nanoparticles with average particle sizes of 19.6 and $64.5 \mathrm{~nm}$, respectively obtained from the M-HMTA precursors of this study compares favorably with those obtained from other starting materials. It can also be observed from Table 4 that our starting materials are the simplest, most readily available, and very cost-effective.

Table 4. Particle sizes (TEM) and morphologies of $\mathrm{Co}_{3} \mathrm{O}_{4}-500$ and $\mathrm{ZnO}-500$ nanoparticles prepared by the thermal decomposition of various precursors at different calcination temperatures

\begin{tabular}{llllll}
\hline \multirow{2}{*}{ Precursor } & \multicolumn{2}{c}{ Calcination } & Particle Size (TEM) (nm) & Morphology & Ref. \\
\cline { 2 - 5 } & \multicolumn{2}{c}{ Time (h) Temp. $\left({ }^{\circ} \mathrm{C}\right)$} & & Pseudo-hexagonal & (de Rivas et al., 2012) \\
\hline $\mathrm{Co}\left(\mathrm{NO}_{3}\right)_{2} \cdot 6 \mathrm{H}_{2} \mathrm{O}+\left(\mathrm{NH}_{4}\right)_{2} \mathrm{CO}_{3}$ & $2-3$ & $300-500$ & $12-14$ & Pseudo-hexagonal & (de Rivas et al., 2012) \\
$\mathrm{Co}(\text { acetate })_{2}+$ oxalic acid & $2-3$ & 500 & $12-14$ & Rounded and squared (Nassar \& Ahmed, 2011) \\
$\mathrm{CoCl}{ }_{2}$ or $\mathrm{Co}\left(\mathrm{NO}_{3}\right)_{2}$ or & 6 & $400-500$ & $30-39$ & & \\
$\mathrm{Co}(\text { acetate })_{2}+$ urea $+\mathrm{CTAB}$ & & & & microdiscs & (Che et al., 2013) \\
$\mathrm{Co}\left(\mathrm{NO}_{3}\right)_{2}+\left(\mathrm{NH}_{4}\right)_{2} \mathrm{OX}$ & 6 & 400 & 25 & Quasi-spherical & (Farhadi \& Safabakhsh, 2012) \\
{$\left[\mathrm{Co}\left(\mathrm{NH}_{3}\right) \mathrm{CO}_{3}\right] \mathrm{NO}_{3} \cdot 0.5 \mathrm{H}_{2} \mathrm{O}$} & 1 & $175-300$ & 10 & Spherical & (Darezereshki et al., 2011) \\
$\mathrm{Zn}\left(\mathrm{SO}_{4}\right)(\mathrm{OH})_{6} \cdot 0.5 \mathrm{H}_{2} \mathrm{O}$ & 1 & 825 & 92 & Hexagonal-like & This work \\
{$\left[\mathrm{Zn}\left(\mathrm{H}_{2} \mathrm{O}\right)_{6}\right](\mathrm{HMTA})_{2}\left(\mathrm{NO}_{3}\right)_{2} \cdot 4 \mathrm{H}_{2} \mathrm{O} 2$} & 500 & 64.5 & &
\end{tabular}

\subsection{Surface Area and Pore Size Analyses}

The surface areas of $\mathrm{Co}_{3} \mathrm{O}_{4}-500$ and $\mathrm{ZnO}-500$ were determined by $\mathrm{N}_{2}$ physisorption. All isotherms (Figure 7) were typical of mesoporous solids (type IV), for which both the surface area and the pore size distribution can be determined (Greg \& Sing, 1982). The hysteresis loops (according to the IUPAC classification) were of type H1, which are often obtained for agglomerates or compacts of spheroidal particles of fairly uniform size and array (Greg \& Sing, 1982). The BET surface areas of the samples (according to Brunauer, Emmett and Teller) are 5.1 and $10.4 \mathrm{~m}^{2} / \mathrm{g}$, respectively. The corresponding Barrett-Joyner-Halenda (BJH) desorption pore sizes are 25 and 12 $\mathrm{nm}$. Table 5 summarizes the results.

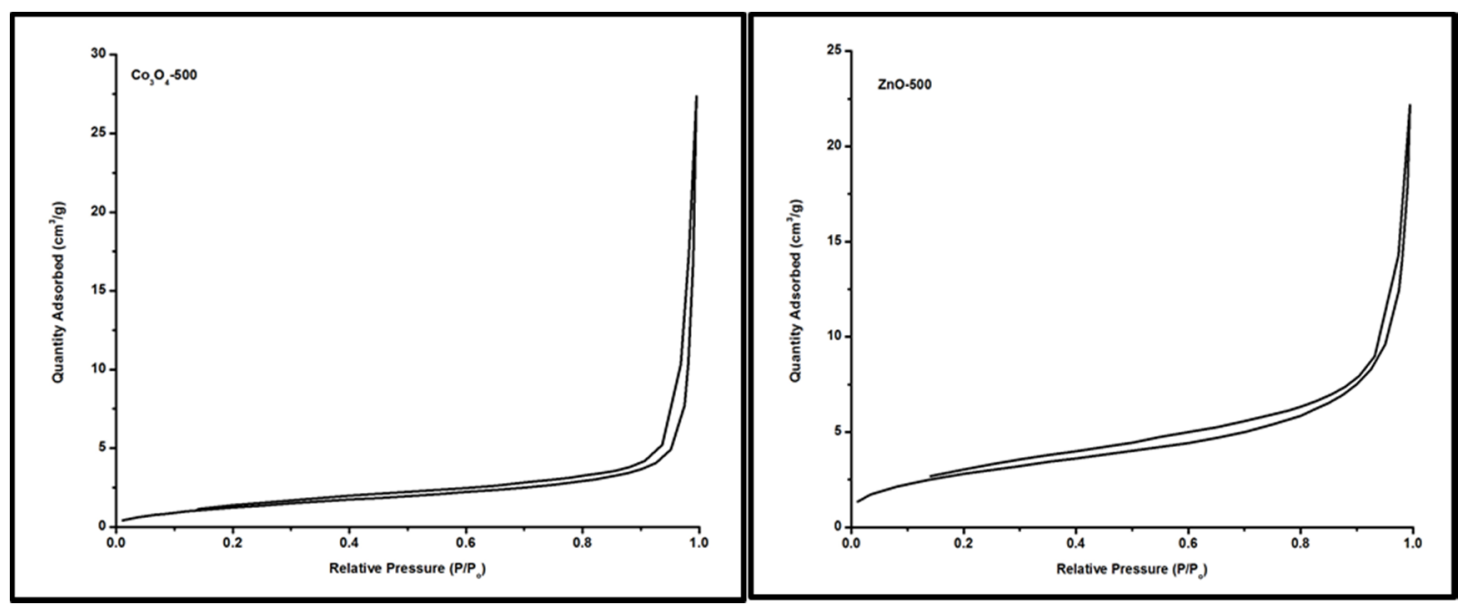

Figure 7. $\mathrm{N}_{2}$ adsorption/desorption isotherms for the $\mathrm{Co}_{3} \mathrm{O}_{4}-500$ and $\mathrm{ZnO}-500$ samples

Table 5. Surface area, average pore diameter (APD) and pore volume of the samples

\begin{tabular}{lccc}
\hline Sample & $\begin{array}{c}\text { BET Surface Area } \\
\left(\mathrm{m}^{2} / \mathrm{g}\right)\end{array}$ & $\begin{array}{c}\text { BJH Desorption APD } \\
(\mathrm{nm})\end{array}$ & $\begin{array}{c}\text { Pore Volume } \\
\left(\mathrm{cm}^{3} / \mathrm{g}\right)\end{array}$ \\
\hline $\mathrm{Co}_{3} \mathrm{O}_{4}-500$ & 5.1 & 25 & 0.043 \\
$\mathrm{ZnO}-500$ & 10.4 & 12 & 0.035 \\
\hline
\end{tabular}




\section{Conclusion}

Pure and crystalline $\mathrm{Co}_{3} \mathrm{O}_{4}$ and $\mathrm{ZnO}$ nanoparticles, with defined morphologies, have been obtained from their corresponding metal-HMTA complexes by thermal decomposition. While $\mathrm{Co}_{3} \mathrm{O}_{4}$ is foam-like, $\mathrm{ZnO}$ nanoparticles have a rod-like shape according to FESEM. The corresponding TEM images confirm cube-like $\left(\mathrm{Co}_{3} \mathrm{O}_{4}\right)$ and hexagonal-prism like $(\mathrm{ZnO})$ morphologies, with average particle sizes of 19.6 and $64.5 \mathrm{~nm}$, respectively. All oxide particles were mesoporous with BET surface areas of $5.1 \mathrm{~m}^{2} / \mathrm{g}\left(\mathrm{Co}_{3} \mathrm{O}_{4}\right)$ and $10.4 \mathrm{~m}^{2} / \mathrm{g}(\mathrm{ZnO})$. This technique that makes use of simple and readily available precursors for metal oxide nanoparticle synthesis could be extended to the synthesis of other metal oxide nanoparticles.

\section{Acknowledgements}

The authors acknowledge assistance by the Electron Microscopy and Tribocorrosion Facility of the Tshwane University of Technology (SEM analyses). The authors thank Dr. Khamlich Saleh (University of Pretoria) for assistance with the TEM images

\section{References}

Afanasiev, P., Chouzier, S., Czeri, T., Pilet, G., Pichon, C., Roy, M., \& Vrinat, M. (2008). Nickel and Cobalt Hexamethylentetramine Complexes $\left(\mathrm{NO}_{3}\right)_{2} \mathrm{Me}\left(\mathrm{H}_{2} \mathrm{O}\right)_{6}(\mathrm{HMTA})_{2} \cdot 4 \mathrm{H}_{2} \mathrm{O}\left(\mathrm{Me}=\mathrm{Co}^{2+}, \mathrm{Ni}^{2+}\right)$ : New Molecular Precursors for the Preparation of Metal Dispersions. Inorganic Chemistry, 47(7), 2303-2311. http://dx.doi.org/10.1021/ic7013013

Aghababazadeh, R., Mazinani, B., Mirhabibi, A., \& Tamizifar, M. (2006). ZnO Nanoparticles Synthesised by mechanochemical processing. Journal of Physics: Conference Series, 26(1), 312.

Ahmad, T., Ganguly, A., Ahmed, J., Ganguli, A. K., \& Alhartomy, O. A. A. (2011). Nanorods of transition metal oxalates: A versatile route to the oxide nanoparticles. Arabian Journal of Chemistry, 4(2), 125-134. http://dx.doi.org/10.1016/j.arabjc.2010.06.041

Banerjee, P., Chakrabarti, S., Maitra, S., \& Dutta, B. K. (2012). Zinc oxide nano-particles: Sonochemical synthesis, characterization and application for photo-remediation of heavy metal. Ultrasonics Sonochemistry, 19(1), 85-93. http://dx.doi.org/10.1016/j.ultsonch.2011.05.007

Bruker. (2001). SMART (Version 5.625), SADABS (Version 2.03a) and SHELXTL (Version 6.12). Madison, Wisconsin, USA: Bruker AXS Inc.

Che, H., Liu, A., Fu, Q., \& Jiang, R. (2013). Facile synthesis of porous cobalt oxide microdiscs and their catalytic property in CO oxidation. Materials Letters, 93(0), 240-242. http://dx.doi.org/10.1016/j.matlet.2012.11.108

Chouzier, S., Afanasiev, P., Vrinat, M., Cseri, T., \& Roy-Auberger, M. (2006). One-step synthesis of dispersed bimetallic carbides and nitrides from transition metals hexamethylenetetramine complexes. Journal of Solid State Chemistry, 179(11), 3314-3323. http://dx.doi.org/10.1016/j.jssc.2006.06.026

Chouzier, S., Vrinat, M., Cseri, T., Roy-Auberger, M., \& Afanasiev, P. (2011). HDS and HDN activity of $(\mathrm{Ni}, \mathrm{Co}) \mathrm{Mo}$ binary and ternary nitrides prepared by decomposition of hexamethylenetetramine complexes. Applied Catalysis A: General, 400(1-2), 82-90. http://dx.doi.org/10.1016/j.apcata.2011.04.023

Dakhlaoui, A., Jendoubi, M., Smiri, L. S., Kanaev, A., \& Jouini, N. (2009). Synthesis, characterization and optical properties of $\mathrm{ZnO}$ nanoparticles with controlled size and morphology. Journal of Crystal Growth, 311(16), 3989-3996. http://dx.doi.org/10.1016/j.jcrysgro.2009.06.028

Darezereshki, E., Alizadeh, M., Bakhtiari, F., Schaffie, M., \& Ranjbar, M. (2011). A novel thermal decomposition method for the synthesis of $\mathrm{ZnO}$ nanoparticles from low concentration $\mathrm{ZnSO}_{4}$ solutions. Applied Clay Science, 54(1), 107-111. http://dx.doi.org/10.1016/j.clay.2011.07.023

de Rivas, B., López-Fonseca, R., Jiménez-González, C., \& Gutiérrez-Ortiz, J. I. (2012). Highly active behaviour of nanocrystalline $\mathrm{Co}_{3} \mathrm{O}_{4}$ from oxalate nanorods in the oxidation of chlorinated short chain alkanes. Chemical Engineering Journal, 184(0), 184-192. http://dx.doi.org/10.1016/j.cej.2012.01.027

Devan, R. S., Patil, R. A., Lin, J.-H., \& Ma, Y.-R. (2012). One-Dimensional Metal-Oxide Nanostructures: Recent Developments in Synthesis, Characterization, and Applications. Advanced Functional Materials, 22(16), 3326-3370. http://dx.doi.org/10.1002/adfm.201201008

Faisal, M., Khan, S. B., Rahman, M. M., Jamal, A., \& Abdullah, M. M. (2012). Fabrication of ZnO nanoparticles based sensitive methanol sensor and efficient photocatalyst. Applied Surface Science, 258(19), 7515-7522. http://dx.doi.org/10.1016/j.apsusc.2012.04.075

Farhadi, S., \& Safabakhsh, J. (2012). Solid-state thermal decomposition of the $\left[\mathrm{Co}\left(\mathrm{NH}_{3}\right)_{5} \mathrm{CO}_{3}\right] \mathrm{NO}_{3} \cdot 0.5 \mathrm{H}_{2} \mathrm{O}$ complex: A simple, rapid and low-temperature synthetic route to $\mathrm{Co}_{3} \mathrm{O}_{4}$ nanoparticles. Journal of Alloys and Compounds, 515(0), 180-185. http://dx.doi.org/10.1016/j.jallcom.2011.11.135 
Fu, L., \& Fu, Z. (2015). Plectranthus amboinicus leaf extract-assisted biosynthesis of $\mathrm{ZnO}$ nanoparticles and their photocatalytic activity. Ceramics International, 41(2, Part A), 2492-2496. http://dx.doi.org/10.1016/j. ceramint.2014.10.069

Gomez, J. L., \& Tigli, O. (2013). Zinc oxide nanostructures: from growth to application. Journal of Materials Science, 48(2), 612-624. http://dx.doi.org/10.1007/s10853-012-6938-5

Greene, L. E., Yuhas, B. D., Law, M., Zitoun, D., \& Yang, P. (2006). Solution-Grown Zinc Oxide Nanowires. Inorganic Chemistry, 45(19), 7535-7543. http://dx.doi.org/10.1021/ic0601900

Greg, S. J., \& Sing, K. S. W. (1982). Adsorption, Surface Area and Porosity (2nd ed.): Academic Press.

Guo, J., \& Peng, C. (2015). Synthesis of $\mathrm{ZnO}$ nanoparticles with a novel combustion method and their $\mathrm{C}_{2} \mathrm{H}_{5} \mathrm{OH}$ gas sensing properties. Ceramics International, 41(2, Part A), 2180-2186. http://dx.doi.org/10.1016/j. ceramint.2014.10.017

Hee Ng, C., Guan Teoh, S., Moris, N., \& Yang Yap, S. (2004). Structural, infrared spectral and thermogravimetric analysis of a hydrogen-bonded assembly of cobalt(II) and nickel(II) mixed complex cations with hexamethylenetetraamine and aqua ligands: $\left\{\left[\mathrm{M}(\mathrm{hmt})_{2}\left(\mathrm{H}_{2} \mathrm{O}\right)_{4}\right]\left[\mathrm{M}\left(\mathrm{H}_{2} \mathrm{O}\right)_{6}\right]\right\}\left(\mathrm{SO}_{4}\right)_{2} \cdot 6 \mathrm{H}_{2} \mathrm{O}$. Journal of Coordination Chemistry, 57(12), 1037-1046. http://dx.doi.org/10.1080/00958970412331281791

Hirai, T., \& Asada, Y. (2005). Preparation of $\mathrm{ZnO}$ nanoparticles in a reverse micellar system and their photoluminescence properties. Journal of Colloid and Interface Science, 284(1), 184-189. http://dx.doi.org/10.1016/j.jcis.2004.09.069

Huang, Y., Chen, C., An, C., Xu, C., Xu, Y., Wang, Y., .. Y Yuan, H. (2014). Synthesis of Cobalt based Complexes and conversion to $\mathrm{Co}_{3} \mathrm{O}_{4}$ nanoparticles as a high performance anode for lithium ion battery. Electrochimica Acta, 145(0), 34-39. http://dx.doi.org/10.1016/j.electacta.2014.08.085

Jensen, J. O. (2002). Vibrational frequencies and structural determinations of hexamethylenetetraamine. Spectrochimica Acta Part A: Molecular and Biomolecular Spectroscopy, 58(7), 1347-1364. http://dx.doi.org/ 10.1016/S1386-1425(01)00585-6

Kahn, M. L., Glaria, A., Pages, C., Monge, M., Saint Macary, L., Maisonnat, A., \& Chaudret, B. (2009). Organometallic chemistry: an alternative approach towards metal oxide nanoparticles. Journal of Materials Chemistry, 19(24), 4044-4060. http://dx.doi.org/10.1039/b818935h

Karami, B., Eskandari, K., Khodabakhshi, S., Hoseini, S. J., \& Hashemian, F. (2013). Green synthesis of three substituted methane derivatives by employing $\mathrm{ZnO}$ nanoparticles as a powerful and recyclable catalyst. $R S C$ Advances, 3(45), 23335-23342. http://dx.doi.org/10.1039/c3ra42993h

Khalaji, A. D., Nikookar, M., Fejfarova, K., \& Dusek, M. (2014). Synthesis of new cobalt(III) Schiff base complex: A new precursor for preparation $\mathrm{Co}_{3} \mathrm{O}_{4}$ nanoparticles via solid-state thermal decomposition. Journal of Molecular Structure, 1071(0), 6-10. http://dx.doi.org/10.1016/j.molstruc.2014.04.043

Klug, H. P., \& (Eds.), L. E. A. (1974). X-ray Diffraction Procedures for Polycrystalline and Amorphous Materials. New York: Wiley.

Lester, E., Aksomaityte, G., Li, J., Gomez, S., Gonzalez-Gonzalez, J., \& Poliakoff, M. (2012). Controlled continuous hydrothermal synthesis of cobalt oxide $\left(\mathrm{Co}_{3} \mathrm{O}_{4}\right)$ nanoparticles. Progress in Crystal Growth and Characterization of Materials, 58(1), 3-13. http://dx.doi.org/10.1016/j.pcrysgrow.2011.10.008

Li, X., Dou, W., \& Bao, N. (2012). Hydrothermal synthesis of tubular ZnO materials. Materials Letters, 68(0), 140-142. http://dx.doi.org/10.1016/j.matlet.2011.10.036

Makhlouf, M. T., Abu-Zied, B. M., \& Mansoure, T. H. (2013). Direct Fabrication of Cobalt Oxide Nanoparticles Employing Sucrose as a Combustion Fuel. Journal of Nanoparticles, 2013, Article ID 384350, 7 pages. http://dx.doi.org/10.1155/2013/384350

Moro, F., Yu Tang, S. V., Tuna, F., \& Lester, E. (2013). Magnetic properties of cobalt oxide nanoparticles synthesised by a continuous hydrothermal method. Journal of Magnetism and Magnetic Materials, 348, 1-7. http://dx.doi.org/10.1016/j.jmmm.2013.07.064

Nassar, M. Y., \& Ahmed, I. S. (2011). Hydrothermal synthesis of cobalt carbonates using different counter ions: An efficient precursor to nano-sized cobalt oxide $\left(\mathrm{Co}_{3} \mathrm{O}_{4}\right)$. Polyhedron, 30(15), 2431-2437. http://dx.doi.org/10.1016/j.poly.2011.05.039

Ndifon, P. T., Agwara, M. O., Paboudam, A. G., Yufanyi, D. M., Ngoune, J., Galindo, A., Alvarez, E., Mohamadou, A. (2009). Synthesis, characterisation and crystal structure of a cobalt(II)-hexamethylenetetramine coordination polymer. Transition Metal Chemistry, 34(7), 745-750. http://dx.doi.org/10.1007/s11243-009-9257-1

Nguimezong, M. B. N., Foba-Tendo, J., Yufanyi, D. M., Etape, E. P., Eko, J. N., \& Ngolui, L. J. (2014). Averrhoa carambola: A Renewable Source of Oxalic Acid for the Facile and Green Synthesis of Divalent Metal (Fe, 
Co, Ni, $\mathrm{Zn}$, and $\mathrm{Cu}$ ) Oxalates and Oxide Nanoparticles. Journal of Applied Chemistry, 2014, Article ID 767695, 9 pages. http://dx.doi.org/10.1155/2014/767695

Niederberger, M. (2007). Nonaqueous Sol-Gel Routes to Metal Oxide Nanoparticles. Accounts of Chemical Research, 40(9), 793-800. http://dx.doi.org/10.1021/ar600035e

Pál, E., Hornok, V., Kun, R., Chernyshev, V., Seemann, T., Dékány, I., \& Busse, M. (2012). Growth of raspberry-, prism- and flower-like $\mathrm{ZnO}$ particles using template-free low-temperature hydrothermal method and their application as humidity sensors. Journal of Nanoparticle Research C7 - 1002, 14(8), 1-14. http://dx.doi.org/10.1007/s11051-012-1002-6

Palacios-Hernández, T., Hirata-Flores, G. A., Contreras-López, O. E., Mendoza-Sánchez, M. E., Valeriano-Arreola, I., González-Vergara, E., \& Méndez-Rojas, M. A. (2012). Synthesis of Cu and Co metal oxide nanoparticles from thermal decomposition of tartrate complexes. Inorganica Chimica Acta, 392(0), 277-282. http://dx.doi.org/10.1016/j.ica.2012.03.039

Rajesh, D., Vara Lakshmi, B., \& Sunandana, C. S. (2012). Two-step synthesis and characterization of ZnO nanoparticles. Physica B: Condensed Matter, 407(23), 4537-4539. http://dx.doi.org/10.1016/j.physb.2012.07.050

Romo, L. E., Saade, H., Puente, B., Lopez, M. L., Betancourt, R., \& Lopez, R. G. (2011). Precipitation of Zinc Oxide Nanoparticles in Bicontinuous Microemulsions. Journal of Nanomaterials, 2011, Article ID 145963, 9 pages. http://dx.doi.org/10.1155/2011/145963

Rui, X., Tan, H., Sim, D., Liu, W., Xu, C., Hng, H. H., ... Yan, Q. (2013). Template-free synthesis of urchin-like $\mathrm{Co}_{3} \mathrm{O}_{4}$ hollow spheres with good lithium storage properties. Journal of Power Sources, 222(0), 97-102. http://dx.doi.org/10.1016/j.jpowsour.2012.08.094

Sharma, G., \& Jeevanandam, P. (2013). Synthesis of $\mathrm{MgO}$ supported $\mathrm{Co}_{3} \mathrm{O}_{4}$ nanoparticles by a novel thermal decomposition approach and studies on their magnetic properties. Microporous and Mesoporous Materials, 165(0), 55-62. http://dx.doi.org/10.1016/j.micromeso.2012.07.034

Sheldrick, G. M. (1997a). SHELXL97, Program for crystal structure refinement. University of Göttingen, Germany. Sheldrick, G. M. (1997b). SHELXS97, Program for Crystal Structure solution. University of Göttingen, Germany.

Singh, G., Baranwal, B. P., Kapoor, I. P. S., Kumar, D., Singh, C. P., \& Fröhlich, R. (2008). Some transition metal nitrate complexes with hexamethylenetetramine: Part LV. Preparation, X-ray crystallography and thermal decomposition. Journal of Thermal Analysis and Calorimetry, 91(3), 971-977. http://dx.doi.org/10.1007/ s10973-007-8615-5

Vijayakumar, S., Ponnalagi, A. K., Nagamuthu, S., \& Muralidharan, G. (2013). Microwave assisted synthesis of $\mathrm{Co}_{3} \mathrm{O}_{4}$ nanoparticles for high-performance supercapacitors. Electrochimica Acta, 106(0), 500-505. http://dx.doi.org/10.1016/j.electacta.2013.05.121

Warang, T., Patel, N., Santini, A., Bazzanella, N., Kale, A., \& Miotello, A. (2012). Pulsed laser deposition of $\mathrm{Co}_{3} \mathrm{O}_{4}$ nanoparticles assembled coating: Role of substrate temperature to tailor disordered to crystalline phase and related photocatalytic activity in degradation of methylene blue. Applied Catalysis A: General, 423424(0), 21-27. http://dx.doi.org/10.1016/j.apcata.2012.02.037

Xiong, H.-M., Ma, R.-Z., Wang, S.-F., \& Xia, Y.-Y. (2011). Photoluminescent ZnO nanoparticles synthesized at the interface between air and triethylene glycol. Journal of Materials Chemistry, 21(9), 3178-3182. http://dx.doi.org/10.1039/c0jm02577a

Xu, H., Gao, L., Zhang, Q., Li, J., Diwu, J., Chou, X., ... Xue, C. (2014, Article ID 723057). Preparation Method of $\mathrm{Co}_{3} \mathrm{O}_{4}$ Nanoparticles Using Degreasing Cotton and Their Electrochemical Performances in Supercapacitors. Journal of Nanomaterials, 2014, 9 pages. http://dx.doi.org/10.1155/2014/723057

Xu, Y., Wang, C., Sun, Y., Zhang, G., \& Gao, D. (2010). Fabrication and characterization of nearly monodisperse $\mathrm{Co}_{3} \mathrm{O}_{4}$ nanospheres. Materials Letters, 64(11), 1275-1278. http://dx.doi.org/10.1016/j.matlet.2010.03.007

Yufanyi, D. M., Tendo, J. F., Ondoh, A. M., \& Mbadcam, J. K. (2014). CdO Nanoparticles by Thermal Decomposition of a Cadmium-Hexamethylenetetramine Complex. Journal of Materials Science Research, 3(3), 1-11. http://dx.doi.org/10.5539/jmsr.v3n3p1

Zhang, Y., Ram, M. K., Stefanakos, E. K., \& Goswami, D. Y. (2012). Synthesis, Characterization, and Applications of ZnO Nanowires. Journal of Nanomaterials, 2012, Article ID 624520, 22 pages. http://dx.doi.org/10.1155/2012/624520

\section{Copyrights}

Copyright for this article is retained by the author(s), with first publication rights granted to the journal.

This is an open-access article distributed under the terms and conditions of the Creative Commons Attribution license (http://creativecommons.org/licenses/by/3.0/). 